J. Dairy Sci. 95:2685-2696

http://dx.doi.org/10.3168/jds.2011-5210

(C) American Dairy Science Association ${ }^{\circledR}, 2012$.

\title{
Forage proportion and particle length affects the supply of amino acids in lactating dairy cows ${ }^{1}$
}

\author{
C. $\mathrm{Li},{ }^{\star} \dagger$ J. Q. Li, ${ }^{\star}$ K. A. Beauchemin, $\dagger$ and W. Z. Yang $\dagger^{2}$ \\ ${ }^{*}$ College of Animal Science, Inner Mongolia Agricultural University, Hohhot, Inner Mongolia, China \\ †Research Centre, Agriculture and Agri-Food Canada, Lethbridge, AB, Canada T1J 4B1
}

\begin{abstract}
This study was conducted to evaluate the effects of dietary factors that alter ruminal fermentability on intake, duodenal flows and intestinal digestibility of individual amino acids (AA) in lactating dairy cows. The experiment was designed as a $4 \times 4$ Latin square using 4 ruminally and duodenally cannulated lactating dairy cows. Treatments were arranged in a $2 \times 2$ factorial design; 2 forage particle lengths (FPL) of alfalfa silage (short and long) were combined with low (35:65) and high (60:40) forage-to-concentrate ratio (F:C; dry matter basis). Four diets were formulated using 2 cuts of alfalfa silage [short $(7.9 \mathrm{~mm})$ and long $(19.1 \mathrm{~mm})$ ], combined with 2 ratios of forage to barley grain concentrate (35:65 and 60:40). Overall, the interactions between dietary $\mathrm{F}: \mathrm{C}$ and FPL on intake, duodenal flows, and intestinal digestibility of AA were marginal. Intakes of total AA and nonessential AA were not different between low- and high-F:C diets, whereas that of essential AA tended to be less with high-F:C diet as a result of lower intakes of Met, Phe, Arg, and His. The flows of total AA and microbial AA were reduced by 22 and $19 \%$, respectively, with increasing $\mathrm{F}$ : $\mathrm{C}$ ratio in the diets due to consistently reduced flows of individual AA, whereas AA profiles (\% of AA-N) of the duodenal protein were not different. Altering F:C from 35:65 to 60:40 decreased the intestinal digestibility of Ile, Leu, Thr, Val, Ala, Cys, and Ser, and consequently, tended to decrease the digestibility of total AA, essential AA, and nonessential AA. Intakes of total AA, essential AA, and nonessential AA were overall not affected by dietary FPL so FPL did not affect the flows or intestinal digestibility of AA. These results indicate that increasing dietary $\mathrm{F}: \mathrm{C}$ ratio decreased overall AA supply because flow to the duodenum and intestinal digestibility of AA were decreased. However, increasing FPL
\end{abstract}

Received November 29, 2011.

Accepted January 14, 2012.

${ }^{1}$ Contribution number 387-11065.

${ }^{2}$ Corresponding author: wenzhu.yang@agr.gc.ca had no effect on AA supply. The measured duodenal flows of AA were consistent with the predictions of the Cornell Net Carbohydrate and Protein System model for the low-forage diet, and were consistent with the National Research Council model for the high-forage diet. Furthermore, the digestibility of individual AA in the intestine varied considerably, regardless of dietary treatment. The results revealed the necessity to consider the both flows and digestibility of individual AA when optimizing ration formulation to meet AA requirements of dairy cows.

Key words: forage-to-concentrate ratio, forage particle length, amino acid, dairy cow

\section{INTRODUCTION}

Protein requirements of dairy cows are met with microbial protein that is produced in the rumen and RUP that escapes the rumen and is absorbed in the intestine. Microbial CP supplies an average of 59\% (range of 34 to $89 \%$ ) of the NAN flow to the duodenum (Clark et al., 1992). In high-producing dairy cows, RUP represents a key contributor to metabolizable AA (NRC, 2001). The supply of individual AA that reach, and are digested, in the small intestine ultimately determines whether or not the protein requirement of the lactating dairy cow is met. The current NRC model (NRC, 2001) expresses protein requirements in term of MP, which is the sum of digested rumen microbial, RUP, and endogenous protein. To improve transfer efficiency of dietary protein into milk protein, the models should ideally define the protein requirement in terms of AA rather than MP. However, this approach is limited by the scarcity of data on the AA profiles of the protein entering at the small intestine and on the intestinal digestibility of individual AA. The flow to the duodenum and the intestinal digestibility of individual AA vary with forage source (Vanhatalo et al., 2009) and grain processing (Yang and Beauchemin, 2004). Recently, the intestinal digestibility of individual AA from RUP was shown to vary widely, depending on the feedstuff and specific AA (Boucher et al., 2009a,b; Mjoun et 
al., 2010). In contrast, NRC (2001) assumes that the intestinal digestibility of individual AA is equal to the digestibility of RUP. Information concerning the supply of AA derived from the diet and the rumen microbes for a range of feeds is limited, yet this information is required for developing accurate protein evaluation systems.

The variations in intestinal AA profiles that determine quantity of individual AA available in the intestine are mainly caused by differences in the AA composition of dietary proteins and in the ratio between microbial protein and RUP (Rulquin and Vérité, 1993). Composition of the feed consumed and the quantity of microbial protein synthesized have a major influence on passage of AA to the duodenum (Overton et al., 1995). It is well documented that dietary factors that alter ruminal OM fermentability also affect ruminal $\mathrm{N}$ metabolism and microbial protein synthesis (Clark et al., 1992; Dewhurst et al., 2000). The duodenal microbial $\mathrm{N}$ flows in beef (Beauchemin et al., 2001) and dairy cattle (Yang et al., 2000) were altered by manipulating extent of grain processing. Changing forage-to-concentrate ratio $(\mathbf{F}: \mathbf{C})$ alters the amount and rate of $\mathrm{OM}$ fermented in the rumen and, thus, can vary microbial protein synthesis (Sniffen and Robinson, 1987; Yang and Beauchemin, 2007b). Adequate particle length of forage is necessary to maintain proper rumen function. Reduced forage particle length (FPL) often negatively affects ruminal microbial protein synthesis (Oba and Allen, 2000; Beauchemin and Yang, 2005). In addition, interactions among dietary factors, such as between F:C and FPL on microbial protein synthesis, have been reported (Rode and Satter, 1988). Increased forage proportion would affect intake of fermentable OM as well as intake of fiber, which could have a significant effect on nutrient supply to dairy cows.

Our previous results on measuring the flows of AA to the duodenum demonstrated the importance of conducting studies to evaluate multiple dietary factors (grain processing, F:C and FPL) rather than a single dietary factor (Yang and Beauchemin, 2004). The supply of AA is key factor to influence milk production and milk protein content of dairy cows. Limited information is available documenting the influence of ruminally fermentable carbohydrates and the effects of dietary FPL on AA supply.

The objective of this study was to evaluate the effects of dietary F:C, FPL, and their interaction on intakes, duodenal flows, and intestinal digestibility of individual AA. The effects on ruminal $\mathrm{pH}$ and fermentation, digestibility, and milk production were also measured but were reported separately (Yang and Beauchemin, 2007a,b).

\section{MATERIALS AND METHODS}

\section{Cows and Diets}

A complete description of the experimental methodology was presented previously (Yang and Beauchemin, 2007b), so only the relevant details are given herein. Four ruminally and duodenally cannulated lactating cows were used in an experiment designed as a $4 \times$ 4 Latin square with a $2 \times 2$ factorial arrangement of treatments; 2 FPL of alfalfa silage (short and long) were combined with low (35:65) and high (60:40) F:C (DM basis). The diets were formulated using the NRC model (NRC, 2001) to supply sufficient energy and protein for a $650 \mathrm{~kg}$ cow to produce $35 \mathrm{~kg} / \mathrm{d}$ of milk containing $3.5 \%$ fat and $3.2 \%$ protein (Table 1 ).

Cows were housed in individual tie-stalls and offered a TMR 3 times daily at 0600, 1500, and $1800 \mathrm{~h}$ for ad libitum intake. The cows, averaging $628 \pm 55 \mathrm{~kg}$ of BW and $65 \pm 20$ DIM, were cared for according to the Canadian Council on Animal Care (Ottawa, ON, Canada) guidelines.

Second-cut alfalfa was harvested at the early bloom stage of maturity and ensiled in large silo bags (200-t capacity) for 2 mo before being used. A forage harvester (model 6910; John Deere, West Bend, WI), equipped with a 37-tooth sprocket and 8 knives, was used to obtain silage chopped at a theoretical chop length of 7.9 and $19.1 \mathrm{~mm}$ for short and long cut silage, respectively. Chemical compositions (DM basis) of alfalfa silage (short vs. long) were DM, 54.9 vs. 51.1\%; NDF, 44.7 vs. $46.2 \%$, and CP, 21.1 vs. $21.3 \%$, respectively.

Each period consisted of $14 \mathrm{~d}$ of adaptation to diets and $7 \mathrm{~d}$ of experimental measurements. Feed offered and orts were measured and recorded daily during the last 7-d of the period to calculate feed intake. Feed samples including alfalfa silage and TMR were collected once weekly, and orts were collected daily and composited weekly for particle length and DM determination. Samples were then composited by period, dried in an oven at $55^{\circ} \mathrm{C}$ for $48 \mathrm{~h}$, and then ground through a 1-mm diameter screen (standard model 4; Arthur Thomas Co., Philadelphia, PA) for chemical analysis.

\section{Duodenal Flow and Apparent Digestion}

Duodenal flow and apparent digestion of protein and AA were determined using $\mathrm{YbCl}_{3}$ (Rhône-Poulenc Inc., Shelton, CT) as a digestive marker. The marker was mixed into the concentrate portion of the diets to supply approximately $1.5 \mathrm{~g}$ of $\mathrm{Yb} / \mathrm{d}$ per cow. Ammonia ${ }^{15} \mathrm{~N}$ $\left(\left[{ }^{15} \mathrm{NH}_{4}\right]_{2} \mathrm{SO}_{4}, 10.6 \%\right.$ atom $\%{ }^{15} \mathrm{~N}$; Isotec Inc., Miamisburg, $\mathrm{OH}$ ) was used as a ruminal microbial marker. 
Table 1. Ingredients and chemical composition of the experimental diets (DM basis)

\begin{tabular}{|c|c|c|c|c|}
\hline \multirow[b]{3}{*}{ Composition } & \multicolumn{4}{|c|}{ Forage $^{1}$ :concentrate $(\mathrm{F}: \mathrm{C})$} \\
\hline & \multicolumn{2}{|c|}{$35: 65$} & \multicolumn{2}{|c|}{$60: 40$} \\
\hline & Short & Long & Short & Long \\
\hline \multicolumn{5}{|l|}{ Ingredient, \% } \\
\hline Alfalfa silage, short cut & 35.7 & - & 59.5 & - \\
\hline Alfalfa silage, long cut & - & 35.7 & - & 59.5 \\
\hline Barley grain, steam rolled ${ }^{2}$ & 56.1 & 56.1 & 31.1 & 31.1 \\
\hline Corn gluten meal & 3.33 & 3.33 & 3.33 & 3.33 \\
\hline Canola meal (Alberta Gold) ${ }^{3}$ & 1.43 & 1.43 & 1.19 & 1.19 \\
\hline Soypass $^{4}$ & 1.43 & 1.43 & 1.19 & 1.19 \\
\hline Beet molasses & 0.48 & 0.48 & 0.95 & 0.95 \\
\hline Calcium carbonate & 0.24 & 0.24 & 0.24 & 0.24 \\
\hline Dicalcium phosphorus & 0.24 & 0.24 & 0.24 & 0.24 \\
\hline Monosodium phosphate & 0.05 & 0.05 & 0.05 & 0.05 \\
\hline Vitamin-mineral $\operatorname{mix}^{5}$ & 0.71 & 0.71 & 0.71 & 0.71 \\
\hline Canola oil & 0.19 & 0.19 & 0.48 & 0.48 \\
\hline Rumen inert fat ${ }^{6}$ & - & - & 0.95 & 0.95 \\
\hline Binding agent $(\mathrm{Aka})^{7}$ & 0.11 & 0.11 & 0.12 & 0.12 \\
\hline \multicolumn{5}{|l|}{ Chemical composition } \\
\hline DM, \% & 72.5 & 71.1 & 66.0 & 62.0 \\
\hline $\mathrm{OM}, \%$ of DM & 93.4 & 93.1 & 91.2 & 90.9 \\
\hline $\mathrm{CP}, \%$ of DM & 19.9 & 20.5 & 21.6 & 21.8 \\
\hline $\mathrm{NDF}, \%$ of DM & 30.3 & 30.6 & 34.5 & 36.4 \\
\hline NDF from forage, $\%$ of $\mathrm{DM}$ & 16.0 & 16.5 & 26.6 & 27.5 \\
\hline $\mathrm{ADF}, \%$ of $\mathrm{DM}$ & 20.4 & 21.6 & 26.9 & 27.4 \\
\hline Starch, \% of DM & 30.6 & 30.6 & 17.8 & 17.8 \\
\hline $\mathrm{NE}_{\mathrm{L}}{ }^{8} \mathrm{Mcal} / \mathrm{kg}$ & 1.65 & 1.65 & 1.65 & 1.65 \\
\hline \multicolumn{5}{|c|}{$\begin{array}{l}{ }^{1} \text { Alfalfa forage was harvested at a theoretical chop length of } 19.1 \text { or } 7.9 \mathrm{~mm} \text { for long- and short-cut silages, } \\
\text { respectively. }\end{array}$} \\
\hline \multicolumn{5}{|c|}{$\begin{array}{l}{ }^{2} \text { Chemical composition of barley grain (DM basis) was } 97.7 \% \text { for OM; } 20.8 \% \text { for NDF; } 7.2 \% \text { for ADF; and } \\
12.4 \% \text { for CP. }\end{array}$} \\
\hline \multicolumn{5}{|c|}{${ }^{3}$ A registered trademark for heat-processed canola meal product (Canbra Foods, Lethbridge, Alberta, Canada). } \\
\hline \multicolumn{5}{|c|}{${ }^{4} \mathrm{~A}$ registered trademark for heat-processed soybean meal product (Borregaard LignoTech, Rothschild, WI). } \\
\hline \multicolumn{5}{|c|}{$\begin{array}{l}{ }^{5} \text { Contained } 58.8 \% \mathrm{NaCl}, 16.0 \% \text { Dynamate (Pitman Moore Inc., Mundelein, IL; } 18 \% \mathrm{~K}, 11 \% \mathrm{Mg}, 22 \% \mathrm{~S} \text {, and } \\
1,000 \mathrm{mg} \text { of } \mathrm{Fe} / \mathrm{kg} \text { ), } 2 \% \mathrm{ZnSO}_{4} \cdot \mathrm{H}_{2} \mathrm{O}, 2.4 \% \mathrm{MnSO}_{4} \cdot 4 \mathrm{H}_{2} \mathrm{O}, 0.01 \% \mathrm{CoSO}_{4} \cdot 6 \mathrm{H}_{2} \mathrm{O}, 0.009 \% \mathrm{Na}_{2} \mathrm{SeO}_{3}, 0.012 \% \text { ethyl- } \\
\text { enediamine dihydroiodide, } 0.8 \% \mathrm{CuSO}_{4} \cdot 5 \mathrm{H}_{2} \mathrm{O}, 2,000,000 \mathrm{IU} \text { of vitamin A} / \mathrm{kg}, 200,000 \mathrm{IU} \text { of vitamin D } / \mathrm{kg} \text {, and } \\
\text { 2,000 IU of vitamin E } / \mathrm{kg} \text {. }\end{array}$} \\
\hline \multicolumn{5}{|c|}{${ }^{6}$ Enertia (ADM Animal Health and Nutrition, Quincy, IL). } \\
\hline \multicolumn{5}{|c|}{${ }^{7}$ Bear River Zeolite of Canada Corp. (Lethbridge, Alberta, Canada). } \\
\hline${ }^{8}$ Estimated from NRC (2001). & & & & \\
\hline
\end{tabular}

Marker solution was continuously infused into the rumen of the cows via the ruminal cannulas using an automatic pump (model $60 \mathrm{RPM} / 7524-10$, Masterflex L/S microprocessor pump drive; Cole-Parmer Instrument Co., Vernon Hills, IL) during the last $11 \mathrm{~d}$ of the period. Daily amounts infused were $140 \mathrm{mg}$ of ${ }^{15} \mathrm{~N}$ dissolved in $800 \mathrm{~mL}$ of water for each cow. Ruminal samples were collected once daily for $4 \mathrm{~d}$ to prepare a mixed bacterial pellet using a differential centrifugation technique (Yang and Beauchemin, 2007b). Bacterial pellets were accumulated by period, freeze dried, ground using a mortar and pestle, and then further ground using a ball mill (Mixer Mill MM2000; Retsch GmbH, Haan, Germany) to a fine powder for determination of $\mathrm{N}$ content and ${ }^{15} \mathrm{~N}$ enrichment.
Duodenal samples were collected 4 times daily every $6 \mathrm{~h}$, moving ahead $2 \mathrm{~h}$ each day for the last $4 \mathrm{~d}$ of infusion. This schedule provided 12 representative samples of duodenal contents taken at 2-h intervals. Each duodenal sample was split into 3 fractions that were pooled by cow within period and retained for ammonia analysis, DM determination after oven-drying at $55^{\circ} \mathrm{C}$, or for chemical analysis after freeze drying. Fecal samples (approximately $200 \mathrm{~g}$ of wet weight) were collected for each cow from the rectum twice daily at various times during the last $6 \mathrm{~d}$ of the period. Fecal samples were immediately subsampled (about $50 \mathrm{~g}$ ), composited across sampling times for each cow and each period, dried at $55^{\circ} \mathrm{C}$, ground to pass a $1-\mathrm{mm}$ sieve (standard model 4; Arthur Thomas Co.), and stored for analysis. 


\section{Chemical Analyses}

Feed DM was determined by oven drying at $55^{\circ} \mathrm{C}$ for $48 \mathrm{~h}$. Analytical DM content of the samples was determined by drying at $135^{\circ} \mathrm{C}$ for $2 \mathrm{~h}(\mathrm{AOAC}, 1990)$. The $\mathrm{OM}$ content was calculated as the difference between DM and ash contents, with ash determined by combustion at $550^{\circ} \mathrm{C}$ overnight. The NDF and $\mathrm{ADF}$ contents were determined using the methods described by Van Soest et al. (1991) with amylase and sodium sulfite used in the NDF procedure. Starch was determined by enzymatic hydrolysis of a-linked glucose polymers, as described by Rode et al. (1999). Content of $\mathrm{N}$ in the samples was determined by flash combustion (model 1500; Carlo Erba Instruments, Milan, Italy). Amino acids in feed and digestive samples were analyzed as the phenylisothiocyanate derivatives by HPLC (WM02; Waters Corp., Milford, MA) according to the procedure of Hagen et al. (1989), with minor modifications in the oxidation step. A sample containing $10 \mathrm{mg}$ of protein was oxidized with $5 \mathrm{~mL}$ of performic acid. One milliliter of concentrated $\mathrm{HCl}$ and 3 drops of 1 -octanol were added to allow samples to sit at $20^{\circ} \mathrm{C}$ before evaporation the next day. For derivatization, $40 \mu \mathrm{L}$ of a derivatized $\mathrm{MeOH}$-water-triethylamine $(2: 2: 1)$ solution was added into the derivatization tubes. The contents were dried by adding the phenylisothiocyanate mixture at $20^{\circ} \mathrm{C}$ and atmospheric pressure.

\section{Calculations and Statistical Analyses}

Flows of CP and AA to the duodenum or the excretion of $\mathrm{CP}$ and $\mathrm{AA}$ in feces were calculated by multiplying DM flow by the respective concentration of $\mathrm{CP}$ or AA in duodenal or fecal DM. The calculations of the flows of DM to the duodenum and DM excreted in feces were described previously (Yang and Beauchemin, 2007b). Flows of microbial AA to the duodenum were estimated based on the microbial $\mathrm{CP}$ flow and $\mathrm{AA}$ composition of bacterial samples isolated from ruminal contents.

Data for intakes and duodenal flows of protein and AA were analyzed using the mixed model procedure of SAS (SAS Institute Inc., Cary, NC) for a $4 \times 4$ Latin square design. The model included treatments (F:C and FPL) and the interaction between F:C and FPL as a fixed effect and period and cow as random effects. The estimation method was restrictive maximum likelihood (REML) and the degrees of freedom method was Kenward-Rogers. Effects of the factors were declared significant at $P<0.05$ and trends were discussed at $P$ $<0.10$, unless otherwise noted.

\section{RESULTS AND DISCUSSION}

\section{Intake of $A A$}

No interactions were observed between F:C and FPL on intakes of total AA, essential AA (EAA) and nonessential AA (NEAA), in contrast to the tendency $(P<0.10)$ for an interaction between $\mathrm{F}: \mathrm{C}$ and $\mathrm{FPL}$ for CP intake (Table 2). Intake of $\mathrm{CP}$ was lower $(P<$ $0.05)$ with high- than with low-F:C diets, whereas the intakes of total AA and NEAA were not different, but the intake of EAA tended $(P<0.09)$ to be less with the high-F:C diet. The greater variation for total AA (SE $=209)$ than for $\mathrm{CP}(\mathrm{SE}=109)$ was the reason that no interaction was observed between F:C and FPL, and no effect of $\mathrm{F}: \mathrm{C}$ occurred. The trend toward less intake of EAA with high $\mathrm{F}: \mathrm{C}$ primarily resulted from less intake of Met $(P<0.01)$ and Phe $(P<0.02)$ as well as a tendency for less intake of $\operatorname{Arg}(P<0.07)$ and His $(P<$ $0.08)$ for cows fed the high-F:C diet. The decrease in intakes of Arg, His, Met, and Phe probably resulted from the substitution of alfalfa silage for barley grain, canola meal, and soybean meal, which had marginally higher concentration (\% of CP) of Arg, His, Met, and Phe than alfalfa silage (NRC, 2001). Intakes of total AA, EAA, and NEAA were not affected by dietary FPL, except for the intakes of Gly $(P<0.03)$ and Ser $(P<$ $0.02)$, which were greater for long than for short FPL. The lack of difference in intakes of total AA, EAA, and NEAA due to FPL was in agreement with a previous report (Yang and Beauchemin, 2004). This effect was expected because the dietary formulation was the same between short and long FPL, and the intake of CP was not affected by FPL. Nevertheless, AA intake is a less meaningful measurement of the real supply of AA to dairy cattle.

\section{Flows of AA to the Duodenum}

The interactions between $\mathrm{F}: \mathrm{C}$ and FPL on flows of $\mathrm{CP}$ and total and individual AA to the duodenum were, overall, not significant (Table 3$)$. The flows of total $(P$ $<0.01)$, microbial $(P<0.04)$, and feed $\mathrm{CP}(P<0.03)$ were less with the high-F:C than with the low-F:C diet. Increasing $\mathrm{F}: \mathrm{C}$ from 35:65 to 60:40 decreased the intake of $\mathrm{CP}$ and the microbial protein production in the rumen without altering ruminal degradability of $\mathrm{CP}$ (Yang and Beauchemin, 2007b). Similarly, the flows of total AA, EAA, NEAA, and individual AA to the duodenum were lower $(P<0.01)$ with the high-F: $\mathrm{C}$ than with the low-F:C diet. The present finding contrasts somewhat to the study by Clark et al. (1992) who reviewed several digestion trials in which diets contained a wide range 
Table 2. Effects of forage-to-concentrate ratio (F:C) and forage particle length (FPL) on AA intake

\begin{tabular}{|c|c|c|c|c|c|c|c|c|}
\hline \multirow[b]{3}{*}{ Item } & \multicolumn{4}{|c|}{ Forage $^{1}$ :concentrate $(\mathrm{F}: \mathrm{C})$} & \multirow[b]{3}{*}{ SE } & \multirow{2}{*}{\multicolumn{3}{|c|}{$P$-value }} \\
\hline & \multicolumn{2}{|c|}{$35: 65$} & \multicolumn{2}{|c|}{$60: 40$} & & & & \\
\hline & Short & Long & Short & Long & & $\mathrm{F}: \mathrm{C}$ & FPL & $\mathrm{F}: \mathrm{C} \times \mathrm{FPL}$ \\
\hline Intake of $\mathrm{DM},{ }^{2} \mathrm{~kg} / \mathrm{d}$ & 20.3 & 20.9 & 18.6 & 18.0 & 0.7 & 0.01 & $\mathrm{NS}^{3}$ & NS \\
\hline Intake of $\mathrm{CP}, \mathrm{g} / \mathrm{d}$ & 4,057 & 4,288 & 4,025 & 3,963 & 109 & 0.05 & NS & 0.10 \\
\hline $\mathrm{AA}, \mathrm{g} / \mathrm{d}$ & & & & & & & & \\
\hline Arg & 134 & 146 & 133 & 122 & 9.4 & 0.07 & NS & NS \\
\hline His & 63 & 72 & 64 & 53 & 6.3 & 0.08 & NS & NS \\
\hline Ile & 108 & 118 & 103 & 112 & 9.2 & NS & NS & NS \\
\hline Leu & 251 & 314 & 268 & 273 & 23.8 & NS & NS & NS \\
\hline Lys & 110 & 130 & 113 & 111 & 13.1 & NS & NS & NS \\
\hline Met & 54 & 53 & 38 & 26 & 6.8 & 0.01 & NS & NS \\
\hline Phe & 154 & 207 & 138 & 139 & 15.1 & 0.02 & NS & 0.10 \\
\hline Thr & 85 & 89 & 83 & 93 & 6.7 & NS & NS & NS \\
\hline Trp & 12 & 18 & 17 & 15 & 2.2 & NS & NS & 0.06 \\
\hline Val & 150 & 160 & 140 & 158 & 9.9 & NS & NS & NS \\
\hline Ala & 153 & 175 & 160 & 176 & 11.4 & NS & 0.09 & NS \\
\hline Asp & 193 & 219 & 228 & 225 & 25.8 & NS & NS & NS \\
\hline Cys & 35 & 38 & 42 & 47 & 2.8 & 0.02 & NS & NS \\
\hline Glu & 664 & 712 & 715 & 694 & 73.9 & NS & NS & NS \\
\hline Gly & 105 & 123 & 105 & 121 & 6.4 & NS & 0.03 & NS \\
\hline Pro & 272 & 306 & 241 & 238 & 19.8 & 0.03 & NS & NS \\
\hline Ser & 106 & 118 & 113 & 143 & 7.4 & 0.04 & 0.02 & NS \\
\hline Tyr & 89 & 105 & 81 & 69 & 9.7 & 0.05 & NS & NS \\
\hline Total AA & 2,958 & 3,134 & 2,809 & 2,846 & 201 & NS & NS & NS \\
\hline Essential AA & 1,212 & 1,306 & 1,097 & 1,101 & 85.3 & 0.09 & NS & NS \\
\hline Nonessential EAA & 1.746 & 1,827 & 1.712 & 1,746 & 128.6 & NS & NS & NS \\
\hline
\end{tabular}

${ }^{1}$ Alfalfa forage was harvested at a theoretical chop length of 19.1 and $7.9 \mathrm{~mm}$ for long- and short-cut silages, respectively.

${ }^{2}$ Data were previously reported (Yang and Beauchemin, 2007b).

${ }^{3} \mathrm{NS}=$ nonsignificant at $P>0.10$.

of forage (from 24 to $81 \%$ ), but failed to establish an optimal F:C that maximized ruminal fermentation and passage of NAN and AA to the duodenum. The authors suggested that simply altering $\mathrm{F}: \mathrm{C}$ does not optimize ruminal fermentation and passage of $\mathrm{AA}$ to the duodenum because the composition of both forages and concentrates contribute to the optimization. Further, the effects of F:C may be related more to the amount and rate of $\mathrm{OM}$ fermentation in the rumen than to the specific $\mathrm{F}: \mathrm{C}$ in the diet. This suggestion is supported by several studies. Moorby et al. (2006) reported a linear decrease of microbial $\mathrm{N}$ flow, along with a linear decrease of ruminal fermented OM, with increasing F:C from 35:65 to 50:50, 65:35, and 80:20. The decrease in microbial AA was consistent with a $1.5 \mathrm{~kg} / \mathrm{d}$ decrease in ruminal fermented OM when feeding a high-F:C rather than a low-F:C diet. This decrease was the result of substituting 25\% silage for $25 \%$ barley grain (Yang and Beauchemin, 2007b). However, altering the F:C did not change the passage of AA to the duodenum in another study (Yang and Beauchemin, 2004) because the highand low-forage diets had equal fermentable $\mathrm{OM}$ and that may explain why no difference existed due to forage level (Yang et al., 2001a). The type of forages and experimental design were different between the present and the previous study (Yang and Beauchemin, 2004) in which alfalfa silage, alfalfa hay, and barley silage were fed, and 3 dietary factors (grain particle size, F:C, and FPL) were investigated, so possible confounding among the factors would be expected. Vanhatalo et al. (2009) reported higher omasal canal AA flows for red clover- than for grass silage-based diets. The results suggest that ruminal fermentability of feeds rather than $\mathrm{F}$ :C was the primary factor determining the flows of AA.

Decreased flows of AA to the duodenum with the high-F:C diet resulted from both lower microbial AA $(P<0.05)$ and dietary AA contents. The relative contribution changed with increasing $\mathrm{F}$ : $\mathrm{C}$; the contribution to total AA flows by microbial AA increased from 55 to $57 \%$, but the contribution by dietary AA decreased from 45 to $43 \%$. Overton et al. (1995) showed that microbial protein production has a major influence on passage of AA to the duodenum. In another study (Yang and Beauchemin, 2004), the effects of $\mathrm{F}: \mathrm{C}$ on microbial AA contribution to duodenal flow of AA depended upon grain particle size; for coarsely rolled barley, increasing $\mathrm{F}: \mathrm{C}$ from $35: 65$ to $55: 45$ increased the proportion of 
LI ET AL.

Table 3. Effects of forage-to-concentrate ratio (F:C) and forage particle length (FPL) on duodenal flows of AA

\begin{tabular}{|c|c|c|c|c|c|c|c|c|}
\hline \multirow[b]{3}{*}{ Item $^{1}$} & \multicolumn{4}{|c|}{ Forage $^{2}$ :concentrate $(\mathrm{F}: \mathrm{C})$} & \multirow[b]{3}{*}{$\mathrm{SE}$} & \multirow{2}{*}{\multicolumn{3}{|c|}{$P$-value }} \\
\hline & \multicolumn{2}{|c|}{$35: 65$} & \multicolumn{2}{|c|}{$60: 40$} & & & & \\
\hline & Short & Long & Short & Long & & $\mathrm{F}: \mathrm{C}$ & FPL & $\mathrm{F}: \mathrm{C} \times \mathrm{FPL}$ \\
\hline \multicolumn{9}{|l|}{$\mathrm{AA}, \mathrm{g} / \mathrm{d}$} \\
\hline Arg & 155 & 151 & 128 & 125 & 12.5 & 0.01 & $\mathrm{NS}^{3}$ & NS \\
\hline His & 70 & 72 & 62 & 53 & 4.9 & 0.01 & NS & NS \\
\hline Ile & 182 & 184 & 154 & 139 & 15.4 & 0.01 & NS & NS \\
\hline Leu & 292 & 308 & 244 & 216 & 21.0 & 0.01 & NS & NS \\
\hline Lys & 193 & 194 & 151 & 128 & 17.4 & 0.01 & NS & NS \\
\hline Met & 48 & 52 & 40 & 36 & 2.6 & 0.01 & NS & 0.04 \\
\hline Phe & 163 & 169 & 142 & 120 & 11.0 & 0.01 & NS & NS \\
\hline Thr & 144 & 146 & 117 & 108 & 12.9 & 0.01 & NS & NS \\
\hline $\operatorname{Trp}$ & 6 & 8 & 8 & 9 & 2.2 & NS & NS & NS \\
\hline Val & 221 & 219 & 180 & 169 & 18.0 & 0.01 & NS & NS \\
\hline Ala & 222 & 238 & 179 & 168 & 19.4 & 0.01 & NS & NS \\
\hline Asp & 303 & 308 & 249 & 234 & 30.5 & 0.01 & NS & NS \\
\hline Cys & 45 & 51 & 40 & 41 & 4.0 & 0.01 & 0.08 & NS \\
\hline Glu & 522 & 585 & 406 & 413 & 58.7 & 0.01 & NS & NS \\
\hline Gly & 190 & 207 & 172 & 153 & 14.0 & 0.01 & NS & 0.06 \\
\hline Pro & 264 & 240 & 209 & 181 & 19.5 & 0.01 & 0.02 & NS \\
\hline Ser & 179 & 172 & 137 & 133 & 15.0 & 0.01 & NS & $\mathrm{NS}$ \\
\hline Tyr & 122 & 130 & 107 & 93 & 7.5 & 0.01 & NS & 0.06 \\
\hline Total AA & 3,321 & 3,433 & 2,725 & 2,518 & 266.8 & 0.01 & NS & $\mathrm{NS}$ \\
\hline EAA & 1,475 & 1,502 & 1,226 & 1,102 & 109.1 & 0.01 & NS & NS \\
\hline NEAA & 1,846 & 1,930 & 1,499 & 1,416 & 159.8 & 0.01 & NS & NS \\
\hline \multicolumn{9}{|l|}{ Bacterial, g/d } \\
\hline Total AA & 1,778 & 1,944 & 1,578 & 1,426 & 233.0 & 0.05 & NS & NS \\
\hline EAA & 867 & 943 & 757 & 692 & 108.7 & 0.04 & NS & NS \\
\hline NEAA & 911 & 1,001 & 821 & 734 & 126.0 & 0.07 & NS & NS \\
\hline \multicolumn{9}{|l|}{ Flows of $\mathrm{CP}, \mathrm{g} / \mathrm{d}$} \\
\hline Total & 4,359 & 4,758 & 3,900 & 3,808 & 387 & 0.01 & NS & NS \\
\hline Feed and endogenous & 2,015 & 2,089 & 1,858 & 1,779 & 146 & 0.03 & NS & NS \\
\hline Microbial & 2,233 & 2,535 & 1,938 & 1,926 & 283 & 0.04 & NS & NS \\
\hline
\end{tabular}

${ }^{1}$ EAA $=$ essential AA; NEAA $=$ nonessential AA.

${ }^{2}$ Alfalfa forage was harvested at a theoretical chop length of 7.9 and $19.1 \mathrm{~mm}$ for short- and long-cut silages, respectively.

${ }^{3} \mathrm{NS}=$ nonsignificant at $P>0.10$.

microbial AA in the flows of total AA from 51 to $69 \%$ and for finely rolled barley, increased F:C increased proportions from 52 to $57 \%$. Those results revealed the complexity of interactions among dietary factors in terms of microbial activity in the rumen of dairy cows.

Flows of CP, total AA, EAA, NEAA, and individual AA to the duodenum were not affected by FPL, except for a reduction $(P<0.02)$ of Pro with long FPL (Table $3)$. The result is consistent with the lack of difference in the amount of ruminally fermented OM between short and long FPL (Yang and Beauchemin, 2007b). Several studies also reported no differences in bacterial flow or total duodenal flows of EAA, NEAA, or total AA due to FPL for steers (Firkins et al., 1986) and dairy cows (Yang and Beauchemin, 2004). The flows of Met $(P<$ $0.04)$, Gly $(P<0.06)$, and Tyr $(P<0.06)$ depended upon an interaction between $\mathrm{F}: \mathrm{C}$ and FPL; flows were higher in low-F:C than in high-F:C diets with short FPL, but the opposite occurred for the long FPL. The results indicated that the effect of dietary FPL on the flows of most AA to the duodenum is minimal.

\section{AA Profiles of Duodenal Protein}

Interactions between $\mathrm{F}: \mathrm{C}$ and $\mathrm{FPL}$ on $\mathrm{AA}$ profiles were, overall, not significant except for Pro and Ser, which were reduced $(P<0.02)$ with long FPL in low F:C, but not with high F:C (Table 4). In general, the profiles of individual EAA were not different either between low and high F:C or between short and long FPL. Only a few NEAA profiles were affected by dietary treatment. The differences in AA profiles of the duodenal protein primarily depended on the variation of AA profiles of ruminal microbial protein, RUP, and the ratio of microbial protein to RUP. The AA profiles of ruminal bacteria are not typically affected by $\mathrm{F}$ :C and FPL (Yang et al., 2001b). Therefore, the present results agree with the conclusion by Rulquin and Vé- 
rité (1993) that variations in intestinal AA profiles are mainly caused by differences in the AA composition of the dietary proteins and in the ratio of microbial protein to RUP. The lack of overall differences in the AA profiles of duodenal protein suggests that the variation in AA profiles of RUP was minimal because the ratio of microbial protein to RUP was relatively constant across the treatments. The present result is consistent with our previous study (Yang and Beauchemin, 2004), which found that the F:C and FPL affected only a few NEAA profiles. However, Mjoun et al. (2010) showed a substantial variation in in situ ruminal degradation of individual AA among and within feedstuff, indicating a potential important influence of RUP on the AA profiles in the duodenal protein. In addition, the slightly decreased Ala with increasing $\mathrm{F}$ : $\mathrm{C}$ was not expected because ruminal bacterial protein have higher Ala (Ludden and Cecava, 1995; Yang et al., 2001b) compared with dietary AA profiles. The discrepancy could be due to the differences in feeds and animals used between the studies. Nevertheless, the present results indicate that dietary factors such as F:C and FPL have minimal effects of biological significance on duodenal AA flows.

\section{Digestibility of AA in the Intestine}

No interaction was observed between F:C and FPL on the intestinal digestibility (\% of duodenal flow) of total and individual AA, except for Ser for which the digestibility tended $(P<0.08)$ to be lower with long compared with short FPL in the low-F: $\mathrm{C}$ diet, yet no effect of FPL was found in the high-F:C diet (Table $5)$. Feeding a high- versus low-F:C diet decreased $(P<$ $0.05)$ the digestibility of Val and Ser, and tended $(P<$ $0.10)$ to decrease the digestibility of Ile, Leu, Thr, Ala, Cys, EAA, NEAA, and total AA. Ben-Ghedalia and Solomon (1988) reported a consistent decrease in the intestinal digestibility of individual AA with increasing proportion of wheat straw (from 0, 30, 70, to 100\%) in place of barley grain in the diets of sheep. In that study, the decrease in AA digestibility was associated with increased fiber-bound $\mathrm{N}$ at the ileum, which indicated that the amount of fiber-bound $\mathrm{N}$ was greater in the ileum than in the diet. These findings suggest that increasing $\mathrm{F}$ : $\mathrm{C}$ in the diets enhances particle-associated bacteria production but its digestion in the small intestine can be partly prevented by the protection of

Table 4. Effects of forage-to-concentrate ratio (F:C) and forage particle length (FPL) on AA profiles of duodenal protein

\begin{tabular}{|c|c|c|c|c|c|c|c|c|}
\hline \multirow[b]{3}{*}{ Item } & \multicolumn{4}{|c|}{ Forage $^{1}$ :concentrate $(\mathrm{F}: \mathrm{C})$} & \multirow[b]{3}{*}{$\mathrm{SE}$} & \multirow{2}{*}{\multicolumn{3}{|c|}{$P$-value }} \\
\hline & \multicolumn{2}{|c|}{$35: 65$} & \multicolumn{2}{|c|}{$60: 40$} & & & & \\
\hline & Short & Long & Short & Long & & $\mathrm{F}: \mathrm{C}$ & FPL & $\mathrm{F}: \mathrm{C} \times \mathrm{FPL}$ \\
\hline \multicolumn{9}{|l|}{$\mathrm{AA}, \%$ of $\mathrm{AA}-\mathrm{N}$} \\
\hline Arg & 4.66 & 4.40 & 4.70 & 4.99 & 0.07 & $\mathrm{NS}^{2}$ & NS & NS \\
\hline His & 2.11 & 2.14 & 2.36 & 2.09 & 0.12 & NS & NS & NS \\
\hline Ile & 5.51 & 5.37 & 5.67 & 5.52 & 0.14 & NS & NS & NS \\
\hline Leu & 8.80 & 9.03 & 9.06 & 8.63 & 0.26 & NS & NS & NS \\
\hline Lys & 5.80 & 5.65 & 5.55 & 5.13 & 0.26 & NS & NS & NS \\
\hline Met & 1.44 & 1.53 & 1.52 & 1.43 & 0.09 & NS & NS & NS \\
\hline Phe & 4.93 & 4.97 & 5.32 & 4.76 & 0.25 & NS & NS & NS \\
\hline Thr & 4.35 & 4.24 & 4.29 & 4.31 & 0.13 & NS & NS & NS \\
\hline Trp & 0.04 & 0.05 & 0.08 & 0.08 & 0.02 & 0.08 & NS & NS \\
\hline Val & 6.70 & 6.38 & 6.60 & 6.70 & 0.16 & NS & NS & NS \\
\hline Ala & 6.67 & 6.95 & 6.56 & 6.69 & 0.11 & 0.01 & 0.01 & NS \\
\hline Asp & 9.13 & 8.95 & 9.06 & 9.27 & 0.37 & NS & NS & NS \\
\hline Cys & 1.35 & 1.48 & 1.47 & 1.65 & 0.08 & NS & NS & NS \\
\hline Glu & 15.73 & 16.93 & 14.63 & 16.45 & 0.96 & NS & NS & NS \\
\hline Gly & 5.72 & 6.06 & 6.43 & 6.13 & 0.25 & 0.07 & NS & NS \\
\hline Pro & 7.99 & 7.00 & 7.70 & 7.19 & 0.18 & NS & 0.01 & 0.02 \\
\hline Ser & 5.40 & 5.04 & 4.97 & 5.27 & 0.14 & NS & NS & 0.02 \\
\hline Tyr & 3.67 & 3.83 & 4.03 & 3.72 & 0.18 & NS & NS & NS \\
\hline $\mathrm{CP}, \%$ of $\mathrm{DM}$ & 29.0 & 31.5 & 27.2 & 27.8 & 1.0 & 0.01 & 0.02 & 0.08 \\
\hline AA-N, \% N & 80.2 & 77.7 & 76.9 & 74.0 & 4.8 & NS & NS & NS \\
\hline EAA-N,${ }^{3} \%$ AA-N & 44.3 & 43.8 & 45.1 & 43.6 & 0.7 & NS & 0.10 & NS \\
\hline
\end{tabular}


Table 5. Effects of forage-to-concentrate ratio (F:C) and forage particle length (FPL) on AA digestibility in the intestine

\begin{tabular}{|c|c|c|c|c|c|c|c|c|}
\hline \multirow[b]{3}{*}{ Item $^{1}$} & \multicolumn{4}{|c|}{ Forage $^{2}$ :concentrate $(\mathrm{F}: \mathrm{C})$} & \multirow[b]{3}{*}{$\mathrm{SE}$} & \multirow{2}{*}{\multicolumn{3}{|c|}{$P$-value }} \\
\hline & \multicolumn{2}{|c|}{$35: 65$} & \multicolumn{2}{|c|}{$60: 40$} & & & & \\
\hline & Short & Long & Short & Long & & $\mathrm{F}: \mathrm{C}$ & FPL & $\mathrm{F}: \mathrm{C} \times \mathrm{FPL}$ \\
\hline \multicolumn{9}{|c|}{ AA, $\%$ of duodenal flow } \\
\hline Arg & 77.0 & 74.7 & 74.2 & 73.9 & 2.5 & $\mathrm{NS}^{3}$ & NS & NS \\
\hline His & 63.4 & 67.0 & 63.3 & 57.4 & 4.5 & NS & NS & NS \\
\hline Ile & 68.8 & 68.3 & 65.7 & 62.8 & 2.9 & 0.09 & NS & NS \\
\hline Leu & 71.3 & 71.7 & 68.7 & 65.8 & 2.8 & 0.07 & NS & NS \\
\hline Lys & 71.1 & 65.8 & 66.8 & 63.8 & 4.9 & NS & NS & NS \\
\hline Met & 68.1 & 73.1 & 67.7 & 66.5 & 4.1 & NS & NS & NS \\
\hline Phe & 65.5 & 67.6 & 65.2 & 58.8 & 3.4 & NS & NS & NS \\
\hline Thr & 68.2 & 64.3 & 62.0 & 60.6 & 3.7 & 0.10 & NS & NS \\
\hline Trp & 40.4 & 50.1 & 61.2 & 56.4 & 12.7 & 0.02 & NS & NS \\
\hline Val & 69.6 & 67.3 & 65.2 & 64.2 & 3.0 & 0.05 & NS & NS \\
\hline Ala & 62.1 & 59.0 & 55.9 & 55.9 & 4.7 & 0.08 & NS & NS \\
\hline Asp & 63.8 & 59.3 & 57.5 & 58.0 & 4.5 & NS & NS & NS \\
\hline Cys & 65.0 & 64.1 & 60.7 & 59.6 & 3.8 & 0.10 & NS & NS \\
\hline Glu & 77.4 & 73.4 & 70.5 & 72.6 & 5.0 & NS & NS & NS \\
\hline Gly & 56.0 & 60.1 & 56.2 & 51.1 & 4.7 & NS & NS & NS \\
\hline Pro & 68.9 & 65.8 & 66.2 & 62.5 & 3.0 & NS & NS & NS \\
\hline Ser & 73.4 & 66.6 & 62.8 & 65.7 & 3.9 & 0.05 & NS & 0.08 \\
\hline Tyr & 64.2 & 62.8 & 57.1 & 53.4 & 6.7 & NS & NS & NS \\
\hline Total AA & 68.9 & 67.2 & 64.6 & 63.4 & 3.5 & 0.08 & NS & NS \\
\hline EAA & 69.9 & 68.9 & 66.9 & 64.2 & 3.0 & 0.09 & NS & NS \\
\hline NEAA & 68.1 & 65.8 & 62.7 & 62.6 & 3.9 & 0.08 & NS & NS \\
\hline \multicolumn{9}{|c|}{ Intestinal AA digested, $\mathrm{g} / \mathrm{d}$} \\
\hline Total AA & 2,337 & 2,363 & 1,808 & 1,615 & 255.9 & 0.01 & NS & NS \\
\hline EAA & 1,041 & 1,045 & 829 & 707 & 99.9 & 0.01 & NS & NS \\
\hline NEAA & 1,296 & 1,319 & 980 & 908 & 158.6 & 0.01 & NS & NS \\
\hline
\end{tabular}

${ }^{1} \mathrm{EAA}=$ essential AA; NEAA $=$ nonessential AA.

${ }^{2}$ Alfalfa forage was harvested at a theoretical chop length of 7.9 and $19.1 \mathrm{~mm}$ for short- and long-cut silages, respectively.

${ }^{3} \mathrm{NS}=$ nonsignificant at $P>0.10$.

particles. Therefore, the trend of decreased intestinal digestibility of total AA, EAA, and NEAA with increased $\mathrm{F}: \mathrm{C}$ may have resulted from a change in the relative proportion of microbial AA to dietary AA. The intestinal digestibility of microbial AA is typically lower than that of dietary AA (Hvelplund and Madsen, 1985; Mjoun et al., 2010). The decrease in the digestibility of Thr, Cys, and Ser with increasing F:C is consistent with previous findings (Yang and Beauchemin, 2004), but a greater number of individual AA were affected by $\mathrm{F}: \mathrm{C}$ in the present study.

The intestinal digestibility (\% of duodenal flow) of total AA, EAA, NEAA, and individual AA were not affected by FPL (Table 5). The results are consistent with the digestibility of $\mathrm{CP}$, which was not different between short and long FPL (Yang and Beauchemin, $2007 \mathrm{~b}$ ). The flows of NDF, CP, and the ratio of microbial $\mathrm{N}$ to dietary $\mathrm{N}$ were not affected by FPL, which may have lead to the similar digestibility of AA in the intestine for the 2 FPL. Digestibility of AA can be affected by the passage of NDF through fiber-bound N and the relative proportion of microbial $\mathrm{N}$ and dietary $\mathrm{N}$ in the intestinal flow.

The digestibility (\% of duodenal flows) of the total AA (averaged 66\%) was higher than that of $\mathrm{CP}$ in the intestine (averaged 61\%; Yang and Beauchemin, 2007b). Santos et al. (1984) reported 4 percentage unit higher intestinal digestibility of AA than that of total N. The greater intestinal digestibility of AA compared with that of $\mathrm{CP}$ is consistent with the report by Hvelplund and Madsen (1985) that the digestibility of either bacterial $\mathrm{CP}$ or feed $\mathrm{CP}$ is lower than that of the respective AA. The difference in the intestinal digestibility of $\mathrm{CP}$ and $\mathrm{AA}$ is in contrast to the previous conclusion that intestinal $\mathrm{N}$ digestibility is a good predictor of AA digestibility (Weisbjerg et al., 1996; Yang and Beauchemin, 2004). Further, the intestinal digestibility of EAA was about 2 to $7 \%$ higher than that of NEAA, which was consistent with studies using dairy cattle (Santos et al., 1984; Yang and Beauchemin, 2004) or a rooster after rumen incubation of samples in dairy cows (Boucher et al., 2009b). These findings 
indicate that preferential absorption of EAA occurred in the small intestine. However, this phenomenon is not accounted for by in vitro (Mjoun et al., 2010) or in mobile bag (Wang et al., 1999; Harstad and Prestløkken, 2001) studies because these techniques usually measure single feeds, no microbial CP production is measured, and no absorption occurs (in vitro).

Digestibilities of individual AA in the intestine were variable among AA and ranged from $40 \%$ for Trp to $77 \%$ for Arg and Glu. The high digestibilities for Arg and Glu are in agreement with Weisbjerg et al. (1996) and Wang et al. (2011). Considerable variation in the digestibility of individual AA was also reported in other in vivo results (Ben-Ghedalia and Solomon, 1988; Yang and Beauchemin, 2004; Boucher et al., 2009b). However, the variation in the digestibility of individual RUP AA for single feeds was small in vitro (Mjoun et al., 2010) or in mobile bags (Wang et al., 1999; Harstad and Prestløkken, 2001), whereas it was great when the residues were fed in roosters. These results demonstrated the differences in the intestinal digestibility of individual AA between in vitro (or in mobile bags) and in vivo.

\section{Supply of $A A$}

A slight difference in AA supply in the intestine compared with duodenal AA flows would be expected due to digestibility of individual AA. For instance, the ratio of EAA to NEAA increased from 0.79 to 0.83 (average of 4 treatments) due to higher digestibility of EAA than of NEAA. Duodenal flow of Phe was $8.6 \mathrm{~g} / \mathrm{d}$ greater than that of Arg, whereas it was $8.9 \mathrm{~g} / \mathrm{d}$ less after adjusted for the digestibility in the intestine. The result suggests that the both duodenal flow and the digestibility of AA need to be considered to improve the accuracy of predicting AA supply to dairy cows.

The NRC (2001) suggested that maximal milk protein production is achieved by formulating diets at concentrations of 7.2 and $2.4 \%$ of MP for Lys and Met, respectively. These concentrations correspond to a Lys-to-Met ratio of 3:1. The ratio of Lys to Met was greater than 3:1 in the current study (3.8) and in the model predictions [NRC, 2001, 3.2; Cornell Net Carbohydrate and Protein System (CNCPS) version 6.1 (http://www.cncps.cornell.edu/downloads.html), 3.1], except for CPM-Dairy (Cornell-Penn-Miner System, version 2.023; University of Pennsylvania, Kennett Square; Cornell University, Ithaca, NY; and William H. Miner Agricultural Research Institute, Chazy, NY), which was 2.7 (Table 6$)$. However, the proportion (\% of EAA flow) of Lys (13.0 and 11.9, respectively, for low- and high-F:C diets), and that of Met (range of 3.2 and 3.4) were lower than recommended by these models. The models recommend Lys and Met at 16.2 and $5.5 \%$, respectively, for NRC (2001) and 16.8 and $5.3 \%$, respectively, for CPM-Dairy (version 2.023). The models (NRC, 2001; CPM-Dairy, version 2.023; and CNCPS, version 6.1 ) predicted a 20 to $27 \%$ deficiency of Lys and a $40 \%$ deficiency of Met.

The duodenal flow of EAA measured in the present study was comparable to that estimated by the CNCPS and higher than that estimated by NRC (2001) and CPM-Dairy (version 2.023) for the low-F:C diet (Table $6)$. However, the measured flow of EAA was close to the estimation by NRC (2001), but different from that

Table 6. Measured versus predicted duodenal flows of essential AA (EAA) using various models ${ }^{1}$ for dairy cows fed low- or high-forage diets

\begin{tabular}{|c|c|c|c|c|c|c|c|c|}
\hline \multirow{3}{*}{$\begin{array}{l}\text { Duodenal flow, } \\
\mathrm{g} / \mathrm{d}\end{array}$} & \multicolumn{8}{|c|}{ Diet } \\
\hline & \multicolumn{4}{|c|}{ Low forage $(35 \%)$} & \multicolumn{4}{|c|}{ High forage $(60 \%)$} \\
\hline & Measured & $\mathrm{NRC}$ & CPM-Dairy & CNCPS & Measured & $\mathrm{NRC}$ & CPM-Dairy & CNCPS \\
\hline $\operatorname{Arg}$ & 153 & 128 & 146 & 190 & 127 & 129 & 123 & 184 \\
\hline His & 71 & 57 & 64 & 83 & 57 & 57 & 54 & 80 \\
\hline Ile & 183 & 136 & 126 & 170 & 147 & 138 & 108 & 168 \\
\hline Leu & 300 & 263 & 212 & 279 & 230 & 265 & 181 & 276 \\
\hline Lys & 194 & 175 & 151 & 194 & 139 & 177 & 130 & 190 \\
\hline Met & 50 & 54 & 57 & 64 & 38 & 54 & 48 & 58 \\
\hline Phe & 166 & 143 & 135 & 182 & 131 & 145 & 114 & 177 \\
\hline Thr & 145 & 136 & 113 & 148 & 113 & 138 & 97 & 145 \\
\hline $\operatorname{Trp}$ & 7 & - & 36 & 49 & 9 & - & 31 & 48 \\
\hline Val & 220 & 154 & 144 & 193 & 174 & 156 & 123 & 191 \\
\hline Total EAA & 1,488 & 1,247 & 1,184 & 1,551 & 1,164 & 1,260 & 1,009 & 1,516 \\
\hline
\end{tabular}

${ }^{1}$ NRC = NRC (2001); CPM-Dairy = Cornell-Penn-Miner System, version 2.023 (University of Pennsylvania, Kennett Square; Cornell University, Ithaca, NY; and William H. Miner Agricultural Research Institute, Chazy, NY); CNCPS = Cornell Net Carbohydrate and Protein System, version 6.1 (http://www.cncps.cornell.edu/ downloads.html). 
estimated by the other 2 models. The flows of EAA estimated by CPM-Dairy decreased with increasing F:C, which is consistent with the measurements; however, the flows estimated by NRC (2001) and the CNCPS were similar between the low- and high-F:C diets. These results indicate that a difference in estimates of $\mathrm{AA}$ supply exists not only between in vivo measurements and prediction models, but also among the models.

\section{Milk Production and Composition}

The effects of F:C and FPL on milk yield and milk composition from the 4 dairy cows used in this study (Table 7) were similar to those for all 12 cows used in the full experiment reported by Yang and Beauchemin (2007b). The actual milk yield of the 4 cows (averaged $27.3 \mathrm{~kg} / \mathrm{d}$ ) was lower than the average of all 12 cows $(32.2 \mathrm{~kg} / \mathrm{d}$; Yang and Beauchemin, 2007b) because of smaller frame size. Increasing the $\mathrm{F}: \mathrm{C}$ ratio of the diet decreased the production of actual milk $(P<0.02)$, $4 \%$ FCM $(P<0.03)$, and SCM $(P<0.01)$, as well as the yield and content of milk protein $(P<0.01)$, but increased $(P<0.03)$ milk fat content. However, no interactions existed between F:C and FPL and no effects of FPL on milk yield and milk composition were observed. Further details of the effects of F:C and FPL on milk production and composition, as well as on DMI, ruminal $\mathrm{pH}$ and fermentation, and nutrient digestibil- ity were discussed previously (Yang and Beauchemin, 2007b). Therefore, only the relationship between the duodenal flows of AA and milk protein production is discussed herein.

The reduction in production of milk, milk protein, and milk protein content were likely due to the deficit in energy supply as a result of decreased DMI with increased F:C. Lower DMI with high-forage diets is thought to be due to the rumen-filling effect of forage. Less starch was digested in the rumen and in the intestine, which would have provided less propionate for glucose synthesis and less glucose for absorption in the intestine with highF:C diets (Yang and Beauchemin, 2007b). The relationship between dietary energy supply and milk protein concentration is well documented (Sutton, 1989); an energy deficit can depress protein percentage by 0.1 to 0.4 percentage units. However, the supply of protein and AA did not limit milk protein production in the present study because milk protein yields were higher $(0.9 \mathrm{~kg} / \mathrm{d})$ in other reports (Overton et al., 1995; Brito et al., 2007; Broderick et al., 2007) than the present value $(0.78 \mathrm{~kg} / \mathrm{d})$ when the same amount of total AA flow to the duodenum was compared (i.e., 2,500 $\mathrm{g}$ of total AA/d). That level corresponds to the lowest flow of total AA observed in the present study. The truly digested $\mathrm{OM}$ in the rumen was higher in the studies of Overton et al. (1995; $9 \mathrm{~kg} / \mathrm{d})$ and Brito et al. (2007; $14 \mathrm{~kg} / \mathrm{d})$ than in the present study $(8 \mathrm{~kg} / \mathrm{d}$; Yang and Beauchemin, 2007b).

Table 7. Effects of forage-to-concentrate ratio (F:C) and forage particle length (FPL) on milk production and composition for lactating dairy cows

\begin{tabular}{|c|c|c|c|c|c|c|c|c|}
\hline \multirow[b]{3}{*}{ Item } & \multicolumn{4}{|c|}{ Forage $^{1}$ :concentrate $(\mathrm{F}: \mathrm{C})$} & \multirow[b]{3}{*}{$\mathrm{SE}$} & \multirow{2}{*}{\multicolumn{3}{|c|}{$P$-value }} \\
\hline & \multicolumn{2}{|c|}{$35: 65$} & \multicolumn{2}{|c|}{$60: 40$} & & & & \\
\hline & Short & Long & Short & Long & & $\mathrm{F}: \mathrm{C}$ & FPL & $\mathrm{F}: \mathrm{C} \times \mathrm{FPL}$ \\
\hline \multicolumn{9}{|l|}{ Milk yield, $\mathrm{kg} / \mathrm{d}$} \\
\hline Actual & 28.5 & 29.0 & 25.6 & 26.1 & 2.2 & 0.02 & $\mathrm{NS}^{2}$ & NS \\
\hline $4 \% \mathrm{FCM}$ & 25.1 & 25.2 & 23.8 & 24.0 & 1.9 & 0.03 & NS & NS \\
\hline SCM & 24.9 & 25.2 & 23.1 & 23.4 & 1.9 & 0.01 & NS & NS \\
\hline \multicolumn{9}{|l|}{ Milk fat } \\
\hline$\%$ & 3.24 & 3.14 & 3.53 & 3.48 & 0.17 & 0.03 & NS & NS \\
\hline $\mathrm{kg} / \mathrm{d}$ & 0.91 & 0.91 & 0.90 & 0.91 & 0.08 & NS & NS & NS \\
\hline \multicolumn{9}{|l|}{ Milk protein } \\
\hline$\%$ & 3.17 & 3.19 & 2.99 & 2.97 & 0.09 & 0.01 & NS & NS \\
\hline $\mathrm{kg} / \mathrm{d}$ & 0.89 & 0.92 & 0.77 & 0.78 & 0.06 & 0.01 & NS & NS \\
\hline \multicolumn{9}{|l|}{ Milk lactose } \\
\hline$\%$ & 4.61 & 4.65 & 4.63 & 4.61 & 0.12 & NS & NS & NS \\
\hline $\mathrm{kg} / \mathrm{d}$ & 1.32 & 1.35 & 1.18 & 1.20 & 0.11 & 0.02 & NS & NS \\
\hline \multicolumn{9}{|l|}{ Milk efficiency } \\
\hline Actual/DMI & 1.40 & 1.39 & 1.39 & 1.44 & 0.08 & NS & NS & NS \\
\hline FCM/DMI & 1.23 & 1.21 & 1.28 & 1.33 & 0.08 & 0.01 & NS & NS \\
\hline $\mathrm{SCC} \times 10^{5}$ & 1.03 & 1.02 & 1.14 & 1.33 & 0.77 & NS & NS & NS \\
\hline
\end{tabular}

\footnotetext{
${ }^{1}$ Alfalfa forage was harvested at a theoretical chop length of 7.9 and $19.1 \mathrm{~mm}$ for short- and long-cut silages, respectively.

${ }^{2} \mathrm{NS}=$ nonsignificant at $P>0.10$.
} 
Mackle et al. (2000) suggested that the mechanism by which increased dietary energy level influences milk protein is related to increased microbial $\mathrm{N}$ synthesis in the rumen, possibly because microbial protein has an AA profile more closely resembling that of milk protein (Santos et al., 1998). In the present study, although the flow of microbial $\mathrm{N}$ (g/d or \% of $\mathrm{N}$ intake) decreased with high-F:C diets, the differences in AA profiles of duodenal protein among treatments were minimal. In addition, the significant interaction between $\mathrm{F}: \mathrm{C}$ and FPL on the duodenal flow of Met did not alter the milk protein content or milk protein yield in a same manner. In fact, the proportions of Met in the EAA were not different among treatments even though they were lower than recommended by the models as discussed above. In the present study, the protein supply seemed to be largely sufficient to meet the requirement of milk protein production due to high $\mathrm{CP}$ content in the diets and high flows of AA. Thus differences in the AA profiles of the duodenal protein did not affect milk protein production.

\section{CONCLUSIONS}

Increasing the $\mathrm{F}: \mathrm{C}$ in the diet reduced the flows of AA to the duodenum as a result of reduced flows of both microbial and feed AA. The intestinal digestibility of AA, EAA, and NEAA tended to decrease with increased rate of forage inclusion in the diets. Consequently, the amount of AA digested in the intestine was significantly decreased by feeding high-F:C compared with low-F:C diets. However, altering FPL had minimal influence on the flows of AA to the duodenum and on the intestinal digestibility of AA. Minimal interaction occurred between F:C and FPL for the flows and digestibility of AA. It was concluded that increasing dietary $\mathrm{F}: \mathrm{C}$ decreased overall AA supply because of a reduction in the flow to the duodenum and decreased intestinal digestibility of AA; however, increasing FPL had no effects on AA supply. Duodenal flows of AA were more accurately predicted by the CNCPS model for the low-forage diet and by the NRC (2001) model for the high-forage diet. The digestibility of EAA in the intestine was slightly but consistently greater than that of NEAA. Furthermore, the digestibility of individual AA varied considerably, regardless of dietary treatment. The results demonstrate the necessity of considering the both flows and digestibility of individual AA for optimizing diet formulation to meet $\mathrm{AA}$ requirements of dairy cows. The flows of AA to the duodenum and the AA profiles had minimal effects on the milk protein production even when energy supply was in deficit because the protein supply was sufficient.

\section{ACKNOWLEDGMENTS}

This experiment was financially supported by the Dairy of Farmers of Canada (Ottawa, ON) and Agriculture and Agri-Food Canada's (Ottawa, ON, Canada) Matching Investment Initiative. The authors thank K. Andrews, B. Farr, A. Furtado, D. Vedres, and R. Wuerfel (of Research Centre, Agriculture and Agri-Food Canada, Lethbridge, AB, Canada) for their assistance in performing sampling and laboratory analyses, and as well as the staff of the Lethbridge Research Centre (Lethbridge, AB, Canada) dairy unit for care of the cows.

\section{REFERENCES}

AOAC. 1990. Official Methods of Analysis. 15th ed. Association of Official Analytical Chemists, Arlington, VA.

Beauchemin, K. A., and W. Z. Yang. 2005. Effects of physically effective fiber on intake, chewing activity, and ruminal acidosis for dairy cows fed diets based on corn silage. J. Dairy Sci. 88:2117-2129.

Beauchemin. K. A., W. Z. Yang, and L. M. Rode. 2001. Effects of barley grain processing on the site and extent of digestion in beef cattle. J. Anim. Sci. 79:1925-1936.

Ben-Ghedalia, D., and R. Solomon. 1988. Amino acids flow to and absorption from the small intestine of sheep fed barley and sulfur dioxide-treated straw at different ratios. Anim. Feed Sci. Technol. $22: 147-159$.

Boucher, S. E., S. Calsamiglia, C. M. Parsons, H. H. Stein, M. D. Stern, P. S. Erickson, P. L. Utterback, and C. G. Schwab. 2009a. Intestinal digestibility of amino acids in rumen undegradable protein estimated using a precision-fed cecectomized rooster bioassay: I. Soybean meal and SoyPlus. J. Dairy Sci. 92:4489-4498.

Boucher, S. E., S. Calsamiglia, C. M. Parsons, H. H. Stein, M. D. Stern, P. S. Erickson, P. L. Utterback, and C. G. Schwab. 2009b. Intestinal digestibility of amino acids in rumen undegradable protein estimated using a precision-fed cecectomized rooster bioassay: II. Distillers dried grains with solubles and fish meal. J. Dairy Sci. 92:6056-6067.

Brito, A. F., G. A. Broderick, J. J. Olmos Colmenero, and S. M. Reynal. 2007. Effects of feeding formate-treated alfalfa silage or red clover silage on omasal nutrient flow and microbial protein synthesis in lactating dairy cows. J. Dairy Sci. 90:1392-1404.

Broderick, G. A., A. F. Brito, and J. J. Olmos Colmenero. 2007. Effects of feeding formate-treated alfalfa silage or red clover silage on the production of lactating dairy cows. J. Dairy Sci. 90:1378-1391.

Clark, J. H., T. H. Klusmeyer, and M. R. Cameron. 1992. Microbial protein synthesis and flows of nitrogen fractions to the duodenum of dairy cows. J. Dairy Sci. 75:2304-2323.

Dewhurst, R. J., D. R. Davies, and R. J. Merry. 2000. Microbial protein supply from the rumen. Anim. Feed Sci. Technol. 85:1-21.

Firkins, J. L., L. L. Berger, N. R. Merchen, and G. C. Fahey Jr. 1986. Effects of forage particle size, level of feed intake and supplemental protein degradability on microbial protein synthesis and site of nutrient digestion in steers. J. Anim. Sci. 62:1081-1094.

Hagen, S. R., B. Frost, and J. Augustin. 1989. Precolumn phenylisothiocyanate derivatization and liquid chromatography of amino acids in food. J. Assoc. Off. Anal. Chem. 72:912-916.

Harstad, O. M., and E. Prestløkken. 2001. Rumen degradability and intestinal indigestibility of individual amino acids in corn gluten meal, canola meal and fish meal determined in situ. Anim. Feed Sci. Technol. 94:127-135.

Hvelplund, T., and J. Madsen. 1985. Amino acid passage to the small intestine in dairy cows compared with estimates of microbial protein and undegraded dietary protein from analysis on the feed. Acta Agric. Scand. 25(Suppl.):21-36. 
Ludden, P. A., and M. J. Cecava. 1995. Supplemental protein sources for steers fed corn-based diets: I. Ruminal characteristics and intestinal amino acid flows. J. Anim. Sci. 73:1466-1475.

Mackle, T. R., D. A. Dwyer, K. L. Ingvartsen, P. Y. Chouinard, D. A Ross, and D. E. Bauman. 2000. Effects of insulin and postruminal supply of protein on use of amino acids by the mammary gland for milk protein synthesis. J. Dairy Sci. 83:93-105.

Mjoun, K., K. F. Kalscheur, A. R. Hippen, D. J. Schingoethe, and D. E. Little. 2010. Lactation performance and amino acid utilization of cows fed increasing amounts of reduced-fat dried distillers grains with solubles. J. Dairy Sci. 93:4144-4154.

Moorby, J. M., R. J. Dewhurst, R. T. Evans, and J. L. Danelón. 2006 Effects of dairy cow diet forage proportion on duodenal nutrient supply and urinary purine derivative excretion. J. Dairy Sci. 89:3552-3562.

NRC. 2001. Nutrient Requirements of Dairy Cattle. 7th rev. ed. Natl. Acad. Sci., Washington, DC.

Oba, M., and M. S. Allen. 2000. Effects of brown midrib 3 mutation in corn silage on productivity of dairy cows fed two concentrations of dietary neutral detergent fiber: 3. Digestibility and microbial efficiency. J. Dairy Sci. 83:1350-1358.

Overton, T. R., M. R. Cameron, J. P. Elliott, J. H. Clark, and D. R. Nelson. 1995. Ruminal fermentation and passage of nutrients to the duodenum of lactating cows fed mixtures of corn and barley. J. Dairy Sci. 78:1981-1998.

Rode, L. M., and L. D. Satter. 1988. Effect of amount and length of alfalfa hay in diets containing barley or corn on site of digestion and rumen microbial protein synthesis in dairy cows. Can. J. Anim. Sci. 68:445-454.

Rode, L. M., W. Z. Yang, and K. A. Beauchemin. 1999. Fibrolytic enzyme supplements for dairy cows in early lactation. J. Dairy Sci. $82: 2121-2126$

Rulquin, H., and R. Vérité. 1993. Amino acid nutrition of dairy cows: Production effects and animal requirements. Pages 55-77 in Recent Advances in Animal Nutrition. P. C. Garnsworthy and D. J A. Cole, ed. Nottingham University Press, UK.

Santos, F. A. P., J. E. P. Santos, C. B. Theurer, and J. T. Huber. 1998. Effects of rumen-undegradable protein on dairy cow performance: A 12-year literature review. J. Dairy Sci. 81:3182-3213.

Santos, K. A., M. D. Stern, and L. D. Satter. 1984. Protein degradation in the rumen and amino acid absorption in the small intestine of lactating dairy cattle fed various protein sources. J. Anim. Sci. $58: 244-255$.

Sniffen, C. J., and P. H. Robinson. 1987. Microbial growth and flow as influenced by dietary manipulations. J. Dairy Sci. 70:425-441.
Sutton, J. D. 1989. Altering milk composition by feeding. J. Dairy Sci. $72: 2801-2814$

Van Soest, P. J., J. B. Robertson, and B. A. Lewis. 1991. Methods for dietary fiber, neutral detergent fiber and non-starch polysaccharide in relation to animal nutrition. J. Dairy Sci. 74:3583-3597.

Vanhatalo, A., K. Kuoppala, S. Ahvenjärvi, and M. Rinne. 2009. Effects of feeding grass or red clover silage cut at two maturity stages in dairy cows. 1. Nitrogen metabolism and supply of amino acids. J. Dairy Sci. 92:5620-5633.

Wang, M., X. G. Zhao, H. Y. Liao, Z. L. Tan, S. X. Tang, Z. H. Sun, C. S. Zhou, and X. F. Han. 2011. Effects of rice straw particle size on digesta particle size distribution, nitrogen metabolism, blood biochemical parameters, microbial amino acid composition and intestinal amino acid digestibility in goats. Anim. Sci. J. 82:78-85.

Wang, Y., T. A. McAllister, M. D. Pickard, Z. Xu, L. M. Rode, and K.-J. Cheng. 1999. Effect of micronizing full fat canola seed on amino acid disappearance in the gastrointestinal tract of dairy cows. J. Dairy Sci. 82:537-544.

Weisbjerg, M. R., T. Hvelplund, S. Hellberg, S. Olsson, and S. Sanne 1996. Effective rumen degradability and intestinal digestibility of individual amino acids in different concentrates determined in situ. Anim. Feed Sci. Technol. 62:179-184.

Yang, W. Z., and K. A. Beauchemin. 2004. Grain processing, forageto-concentrate ratio, and forage length effects on ruminal nitrogen degradation and flows of amino acids to the duodenum. J. Dairy Sci. 87:2578-2590

Yang, W. Z., and K. A. Beauchemin. 2007a. Altering physically effective fiber intake through forage proportion and particle length: Chewing and ruminal pH. J. Dairy Sci. 90:2826-2838.

Yang, W. Z., and K. A. Beauchemin. 2007b. Altering physically effective fiber intake through forage proportion and particle length: Digestion and milk production. J. Dairy Sci. 90:3410-3421.

Yang, W. Z., K. A. Beauchemin, and L. M. Rode. 2000. Effects of barley grain processing on extent of digestion and milk production of lactating cows. J. Dairy Sci. 83:554-568.

Yang, W. Z., K. A. Beauchemin, and L. M. Rode. 2001a. Effects of grain processing, forage to concentrate ratio, and forage particle size on rumen $\mathrm{pH}$ and digestion by dairy cows. J. Dairy Sci. $84: 2203-2216$

Yang, W. Z., K. A. Beauchemin, and L. M. Rode. 2001b. Effect of dietary factors on distribution and chemical composition of liquid- or solid-associated bacterial population in the rumen of dairy cows. J. Anim. Sci. 79:2736-2746. 